\section{Commentary: Endoscopic device closure to fix the dam problem of postpneumonectomy bronchopleural fistula}

\author{
Abbas E. Abbas, MD, MS, FACS
}

The dreaded complication of postpneumonectomy bronchopleural fistula (PP-BPF) has been the scourge of thoracic surgery since the first pneumonectomy, an operation that requires closure of a potentially ischemic bronchial stump. Sealing the bronchus creates a barrier between the sterile pleural space and the heavily colonized airway. Any breach of this dam may lead to fulminant empyema and spillover aspiration pneumonia in the contralateral lung. Such a patient usually presents with sepsis and respiratory failure. Emergency management includes drainage of the pleural cavity and placing the pneumonectomy side down. Once stabilized, urgent surgical management is indicated. Our preferred approach is the modified Clagett procedure in 2 stages: first is open pleural drainage, closure of fistula, muscle transposition, and debridement, whereas the second stage is obliteration of the pleural space and closure of the chest wall. Other approaches to close the bronchial fistula include sternotomy for transpericardial exposure, mediastinoscopy for transcervical stapling, and right thoracotomy for closure of left PP-BPF. When closure of the stump fails, the remaining options include a large open window thoracostomy such as the Eloesser flap, or even a 2-stage thoracoplasty. ${ }^{1}$

This maximally invasive approach may not always be necessary, especially when the fistula is small, and the

\footnotetext{
From the Division of Thoracic Surgery, Department of Thoracic Medicine and Surgery, Temple University Hospital and Fox Chase Comprehensive Cancer Center, Lewis Katz School of Medicine, Philadelphia, Pa.

Disclosures: The author reported no conflicts of interest.

The Journal policy requires editors and reviewers to disclose conflicts of interest and to decline handling or reviewing manuscripts for which they may have a conflict of interest. The editors and reviewers of this article have no conflicts of interest.

Received for publication Sept 1, 2020; revisions received Sept 1, 2020; accepted for publication Sept 4, 2020; available ahead of print Sept 15, 2020.

Address for reprints: Abbas E. Abbas, MD, MS, FACS, Department of Thoracic Medicine and Surgery, Temple University Hospital and Fox Chase Comprehensive Cancer Center, Lewis Katz School of Medicine, 3401 N Broad St, Suite C-500, Philadelphia, PA 19035 (E-mail: abbas.abbas@temple.edu).

JTCVS Techniques 2020;4:349-50

2666-2507

Copyright (C) 2020 The Authors. Published by Elsevier Inc. on behalf of The American Association for Thoracic Surgery. This is an open access article under the CC BY-NCND license (http://creativecommons.org/licenses/by-nc-nd/4.0/).

https://doi.org/10.1016/j.xjtc.2020.09.008
}

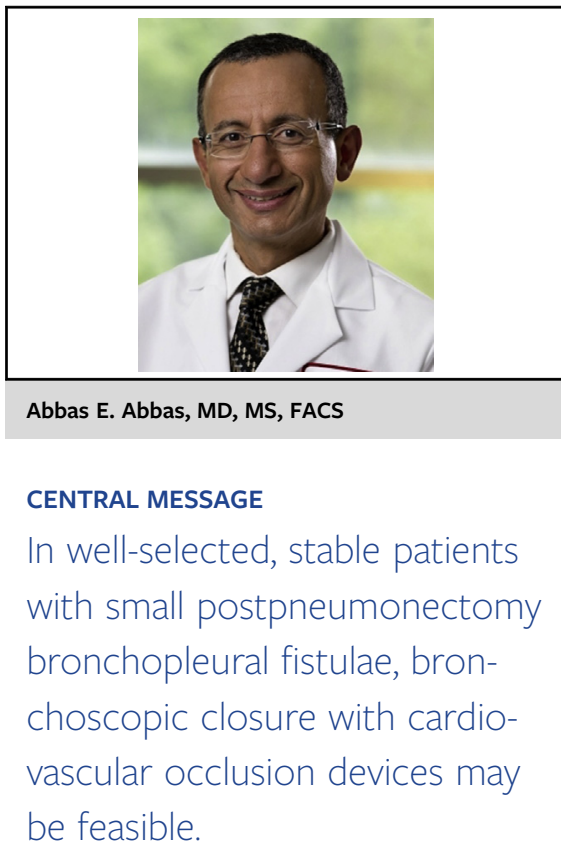

clinical picture is subtler with only mild clinical or radiological findings. Such patients may be amenable to endoscopic therapy, including direct tissue abrasion, sealant glues or occlusive devices such as coils, endobronchial valves, or cardiovascular closure plugs. Success with these techniques has been variable and there is lack of consensus on the best approach. ${ }^{2}$

Menzes and colleagues ${ }^{3}$ present a case report of a small left PP- BPF that was successfully closed with an Amplatzer Vascular Plug II (St. Jude Medical, St. Paul, Minn) deployed across the BPF. Eight weeks previously, the 64-year-old female patient had undergone left intrapericardial pneumonectomy with intercostal muscle flap bronchial coverage for non-small cell lung cancer after induction immunotherapy. This patient's only symptom was cough and bronchoscopy showed a $2-\mathrm{mm}$ BPF in a viable left mainstem bronchial stump. ${ }^{3}$

This is yet another report of using an Amplatzer-type device for this indication. Kramer and colleagues ${ }^{4}$ first described this technique in 2008 using an atrial septal defect occluder. ${ }^{4}$ In 2011, the same group updated their series to describe successful BPF closure in 9 of 10 patients. ${ }^{5}$ Since then, there have been numerous reports of successfully reproducing this technique. ${ }^{6,7}$

Of note, there is a large lineup of different Amplatzer occlusion devices specifically designed for percutaneous transcatheter closure of different cardiovascular defects; for example, patent foramen ovale, atrial septal defect, ventricular septal defect, patent ductus arteriosus, and 
peripheral vascular embolization. All are contraindicated in the presence of endocarditis or other infection. Additionally, none of these devices are specifically designed for, or Food and Drug Administration approved for, use in the airway. As such, any use for a BPF in the setting of a potentially infected airway must be considered offlabel.

One must always remember that the danger to patients with PP-BPF comes not from the hole in the airway but from the breach of the barrier to the pleural cavity. The first order of business must always be to prevent or treat infection of that space. Closing the hole comes secondary because any closure, whether surgical or endoscopic, will inevitably fail if performed in a contaminated field. When the PP-BPF is large or the stump appears necrotic, surgical repair as outlined above will be necessary. However, in well-selected, stable patients with a small fistula and a healthy bronchial stump, endoscopic therapy may be reasonable and when successful is certainly much less invasive than the surgical procedures. Plugging the fistula with a vascular occlusion device in this setting is akin to the Dutch boy who held back the sea and saved his country by simply using his finger to plug a leak in the dam. ${ }^{8}$

\section{References}

1. Abbas A-S, Deschamps C. Postpneumonectomy empyema. Curr Opin Pulm Med. 2002;8:327-33

2. Lois M, Noppen M. Bronchopleural fistulas: an overview of the problem with special focus on endoscopic management. Chest. 2005;128:3955-65.

3. Menezes V, Soder S, Kadadah S, Masson JB, Lafontaine E, Liberman M. Bronchoscopic treatment of a bronchopleural fistula after pneumonectomy. J Thorac Cardiovasc Surg Tech. 2020;4:345-8.

4. Kramer MR, Peled N, Shitrit D, Atar E, Saute M, Shlomi D, et al. Use of Amplatzer device for endobronchial closure of bronchopleural fistulas. Chest. 2008;133:1481-4.

5. Fruchter O, Kramer MR, Dagan T, Raviv Y, Abdel-Rahman N, Saute M, et al. Endobronchial closure of bronchopleural fistulae using Amplatzer devices: our experience and literature review. Chest. 2011;139:682-7.

6. Gulkarov I, Paul S, Altorki NK, Lee PC. Use of Amplatzer device for endobronchial closure of bronchopleural fistulas. Interact Cardiovasc Thorac Surg. 2009;9: 901-2.

7. Tedde ML, Scordamaglio PR, Minamoto H, Figueiredo VR, Pedra CC, Jatene FB Endobronchial closure of total bronchopleural fistula with Occlutech Figulla ASD N device. Ann Thorac Surg. 2009;88:e25-6.

8. Hort L, Locker T, Dodge MM. The Boy Who Held Back the Sea. New York, NY: Puffin Books; 1993. 